\title{
Concept of Lean Production Using Marginal Analysis in Conditions of Innovation Economics
}

\author{
Dolzhenkova E. \\ Nizhny Tagil Technological Institute (branch) \\ Ural Federal University, UrFU \\ Ekaterinburg, Russia \\ lenag1981@mail.ru
}

\author{
Iurieva L. \\ Graduate School of Economics and Management \\ Ural Federal University, UrFU \\ Ekaterinburg, Russia \\ 1.v.iuryeva@urfu.ru
}

\begin{abstract}
The article develops an algorithm for optimizing the orders portfolio of iron and steel companies based on marginal profitability analysis, which allows one to reduce "overproduction losses" of rolled metal products, as well as losses for carrying out the calculations - "expectation losses", in conditions of innovation economy. The subject of the authors' study was economic relations arising at steel-making companies under lean production. Scientific papers of domestic and foreign scientists, statistical reports data and the results of approbation of the optimization algorithm of the orders portfolio at steelproducing companies have formed the theoretical and methodological basis of the study. The calculations have revealed that the proposed algorithm for optimizing iron and steel companies' orders portfolio, based on the marginal analysis, has made it possible to economically justify the necessity of lean manufacturing tools implementation for companies operating in the industry under innovation economics and to reduce losses from expectations and overproduction, which do not add value to the consumer.
\end{abstract}

Keywords - Innovations, lean production, marginal analysis

\section{INTRODUCTION}

Currently, the innovation vector is aimed at stimulating the development of the Russian industrial enterprises, industries and regions. Such situation can have a cumulative effect on the potential of the Russian economy, ensure the growth of competitiveness of domestic goods and services, accelerate modernization of machinery and technologies, address social problems of society.

In recent years, the state has actively implemented measures aimed at the development of the national innovation system (NIS) of Russia (Fig. 1).

A number of state development institutions activate innovative processes and infrastructure potential using publicprivate partnership mechanisms (eg. Agency for Strategic Initiatives, Vnesheconombank, RUSNANO, Market for Innovations and Investments of the Moscow Stock Exchange, Foundation for Infrastructure and Educational Programs, SKOLKOVO).

In addition to creation of state institutions for development, amendments aimed at reducing tax duty for innovation-active organizations were added to the Tax Code of the Russian Federation:

- reduction of tariffs for insurance payments;

- improvement of depreciation policy;

- tax support for personal income tax payers.

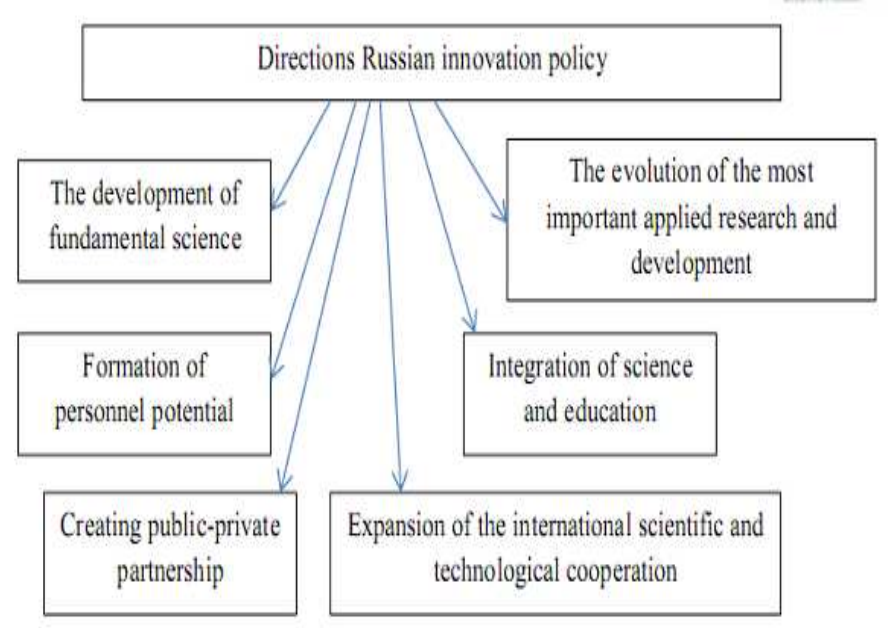

Fig. 1. Directions of the Russian innovation policy

However, it is impossible to talk about the effectiveness of measures of the innovation system of development in conditions of turbulence of external and internal environment (Fig. 2).

In such conditions of risks and uncertainties, it is difficult to predict the state of innovation activities of industrial enterprises, industries and regions of Russia.

Determining the company's financial indicators is one of the top priorities, as they reflect its financial standing and characterize impact of the economic situation in the country on the results of the steel-producing company financial and economic activities.

Functioning of large-scale steel-producing companies under market relations conditions largely depends on the wellcoordinated work of their divisions and sound financial 
planning, one of the main tools of which is the analysis of marginal profitability.

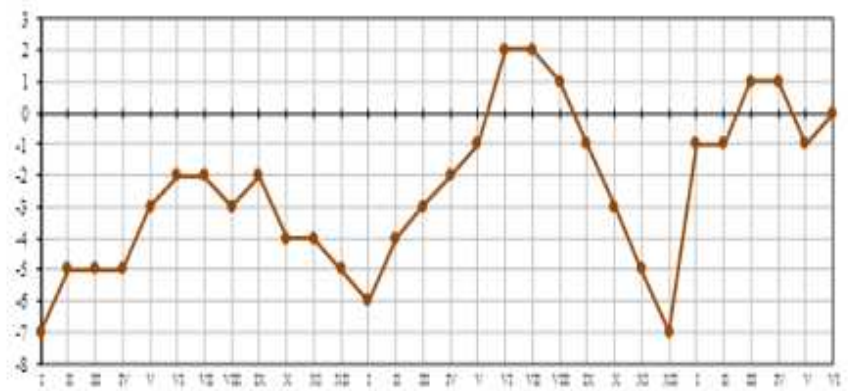

2015

2016

2017

a) for extraction of minerals

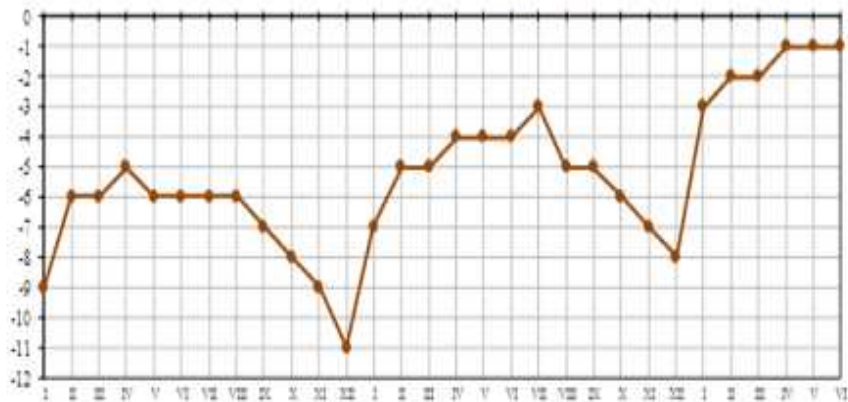

2015

2016

2017

b) manufacturing industries

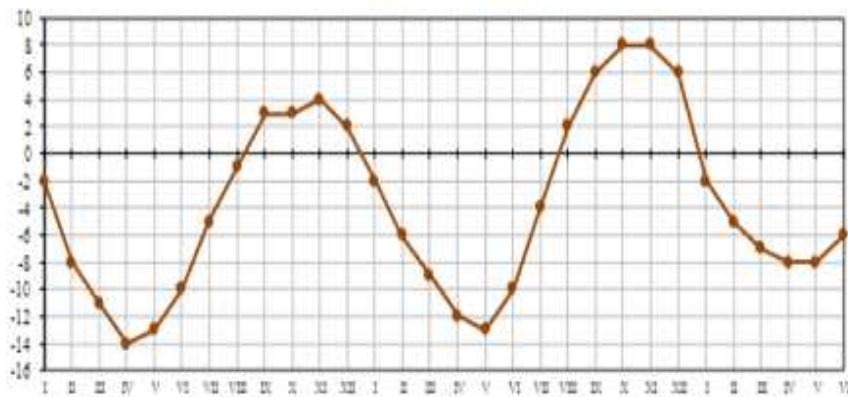

2015

2016

2017

c) for providing electric power, gas and steam

Fig. 2. Index of entrepreneurial confidence of organizations (without small enterprises)

Break-even analysis, based on studying relationship between the three groups of economic indicators: costs, volume of production (sale) and profit, and forecasting of each indicator rate at a given value of others, in the authors' opinion, will make it possible to economically justify the occurrence of various types of losses, while implementing the concept of lean manufacturing, and will allow one to propose measures of their reduction. Many global manufacturers work today moving along the path of lean manufacturing, the main idea of which says: "Everything that does not add value to consumer must be eliminated."
The aim of the research is to develop an algorithm for optimizing the orders portfolio of iron and steel companies on the basis of marginal profitability analysis, which allows to reduce rolled metal products "overproduction losses", as well as losses for calculating - "expectation losses".

Use of scientific and methodological developments, contained in the research, will ensure the reduction of various types of losses, which do not add value to consumer, and make it possible to economically justify the necessity of lean production tools implementation at steel-producing companies operating in innovation economics conditions. Under the innovation economics, the authors consider a modern stage of social development, when the growth and evolution of the entire economic system are provided not so much by external factors, but by internal factors, the most important of which are knowledge and human capital [1].

There are different views on the role of marginal analysis while implementing the lean production concept at steelproducing companies in conditions of innovation economics. An empirical study of marginal productivity theory is given in the work of Biewen, M., Weiser, C. [2]. The authors suppose that size of a firm has direct impact on size of the marginal profit of Chilian enterprises. Marginal analysis has made it possible to derive a general version of Pigou's law in the study of Snow, A., Warren, R.S., Jr. [3]. A new mechanism for determining excess power in economics based on marginal analysis is given in the work of Murphy, D. [4].

Practical experience of «lean production» logistic theory use is described in the studies of Sahno, J., Shevtshenko, E., Karaulova, T., Tahera, K. [5, 6, 7]; Breuer C., Siestrup G., Haasis H.-D., Wildebrand H. [8]; Wiengarten F., Fynes B., Onofrei G. [9]; Paulraj A. [10, 11]; Holweg M. [12]; Sakakibara S., Flynn B.B., Schroeder R.G., Morris W.T. [13] and others.

Interesting approaches of using $\mathrm{ABC}$-analysis are presented in the works of Alsharari N.M. [14]; Askarany D., Yazdifar H., Askary S. [15].

Building of economic models in context of innovation economics can be found in the studies of: Borch K.H. [16]; Marinacci M. [17]; Li, Ya., Li, Yo., Zhao, Y. [18] and others.

A review of existing scientific works and statistical reporting data presented by the Federal State Statistics Service has allowed to identify the following trends in the management of industrial enterprises innovation processes in conditions of internal and external turbulence (Table I).

\section{A. Focus on final results}

Management of industrial enterprises increases interest in technological innovation.

Costs for research and development, as well as the number of advanced manufacturing technologies including machines, devices, equipment and devices based on microelectronics or controlled by computer increase. 


\section{B. Improvement of consumer services quality}

It is necessary to identify the costs of servicing of industrial enterprises customers more accurately in order to modify the range of provided services, taking into account the characteristics of individual customers. As a result, the scale of paid services, provided to the Russian people, has been growing in 1991-2017.

\section{Prevalence of the principles of complementary and synergetic approaches to the development of innovative industrial enterprises}

Application of the synergetic approach can give the greatest results when it is necessary to implement rapid changes in the system. Application of the complementary approach is necessary in the context of innovation processes target management when there is an opportunity of development and sequential realization of the planned changes.

TABLE I. TRENDS IN THE MANAGEMENT OF INNOVATION PROCESSES IN INDUSTRIAL ENTERPRISES

\begin{tabular}{|c|c|c|}
\hline Trend & Characteristic & Result \\
\hline Focus on final results & $\begin{array}{l}\text { Implementation of } \\
\text { technological } \\
\text { innovations }\end{array}$ & $\begin{array}{l}\text { Gaining a } \\
\text { technological } \\
\text { competitive advantage }\end{array}$ \\
\hline $\begin{array}{l}\text { Improvement of the } \\
\text { quality of consumer } \\
\text { services }\end{array}$ & $\begin{array}{l}\text { Development of a } \\
\text { "proposal" that can } \\
\text { positively affect the } \\
\text { buyers perception of } \\
\text { the value they will } \\
\text { have from buying the } \\
\text { goods }\end{array}$ & $\begin{array}{l}\text { Gaining a service } \\
\text { competitive advantage }\end{array}$ \\
\hline $\begin{array}{l}\text { Prevalence of the } \\
\text { principles of } \\
\text { complementary and } \\
\text { synergetic approaches } \\
\text { to the development of } \\
\text { innovative industrial } \\
\text { enterprises }\end{array}$ & $\begin{array}{l}\text { Rational resource } \\
\text { management in } \\
\text { conditions of } \\
\text { turbulence of external } \\
\text { and internal } \\
\text { environment }\end{array}$ & $\begin{array}{l}\text { Innovative } \\
\text { development of } \\
\text { industrial enterprises }\end{array}$ \\
\hline $\begin{array}{l}\text { Enhancement of the } \\
\text { information } \\
\text { technology role }\end{array}$ & $\begin{array}{l}\text { Increase in the speed } \\
\text { of response to actual } \\
\text { demand }\end{array}$ & $\begin{array}{l}\text { Reduction of } \\
\text { economic environment } \\
\text { uncertainty }\end{array}$ \\
\hline $\begin{array}{l}\text { Underdevelopment of } \\
\text { financial mechanisms } \\
\text { in management }\end{array}$ & $\begin{array}{l}\text { Decrease in the } \\
\text { efficiency of the } \\
\text { industrial enterprises }\end{array}$ & $\begin{array}{l}\text { Reduction of the } \\
\text { possibility of making a } \\
\text { rational managerial } \\
\text { decision }\end{array}$ \\
\hline
\end{tabular}

\section{Enhancement of the information technology role}

Reasons for the growth of the role of information flows are indicated below.

- Availability of complete and reliable information reduces the necessity of inventories and labor resources.

- Information increases flexibility of industrial enterprises.

\section{E. Underdevelopment of financial mechanisms in management}

Studying of the statistical data has identified the industrial enterprises production-limiting factors (Table II):

- lack of skilled workers;

- lack of financial resources;

- high percentage of commercial loans;

- uncertainty of the economic situation;

- lack of equipment;

- high level of taxation;

- competing import;

- insufficient demand in the domestic market;

- insufficient demand in the external market.

TABLE II. RATING OF THE PRODUCTION-LIMITING FACTORS OF INDUSTRIAL ENTERPRISES

\begin{tabular}{|l|c|c|}
\hline \multicolumn{1}{|c|}{$\begin{array}{c}\text { Production-limiting factors of } \\
\text { industrial enterprises }\end{array}$} & $\begin{array}{c}\text { Average } \\
\text { place }\end{array}$ & $\begin{array}{c}\text { Percentage of } \\
\text { respondents }\end{array}$ \\
\hline $\begin{array}{l}\text { 1. Insufficient demand in the domestic } \\
\text { market }\end{array}$ & 1.2 & $40-45 \%$ \\
\hline 2. High level of taxation & 1.8 & $40-45 \%$ \\
\hline 3. Uncertainty of the economic situation & 3.3 & $35-40 \%$ \\
\hline 4. Lack of financial resources & 3.7 & $35-40 \%$ \\
\hline 5. High percentage of commercial loans & 5.0 & $25-30 \%$ \\
\hline 6. Lack of skilled workers & 6.6 & $25-30 \%$ \\
\hline 7. Competing import & 7.1 & $25-30 \%$ \\
\hline 8. Lack of equipment & 7.4 & $20-25 \%$ \\
\hline $\begin{array}{l}\text { 9. Insufficient demand in the external } \\
\text { market }\end{array}$ & 9.0 & $20-25 \%$ \\
\hline
\end{tabular}

The most significant production-limiting factors of industrial enterprises are insufficient demand, high level of taxation, uncertainty of the economic situation and lack of financial resources.

It should be noted that a lack of financial resources can cause inefficient operation of industrial enterprises: the possibility of making a rational managerial decision is reduced.

A given overview of scientific studies has allowed to generalize the accumulated experience and to reveal absence of technologies for orders portfolio forecasting in conditions of innovation economics, provided that various types of losses not adding value to consumer are reduced.

\section{RESEARCH METHODS}

The algorithm for orders portfolio optimization is designed to select an effective option for selling rolled metal products to the domestic market, which will allow the enterprise to obtain the biggest profit and to reduce losses that do not create added value. 
(Fig. 3):

The proposed algorithm includes the following main steps

- First, the maximum marginal profit for all the bar shapes is calculated on the basis of its ranking in descending order. Then, the production capacity of each type is determined;

- If the possibility of production is confirmed, it is checked whether the production shop has the required quantity of steel for organizing manufacturing;

- Type of the billet is checked - continuous cast or hot rolled.

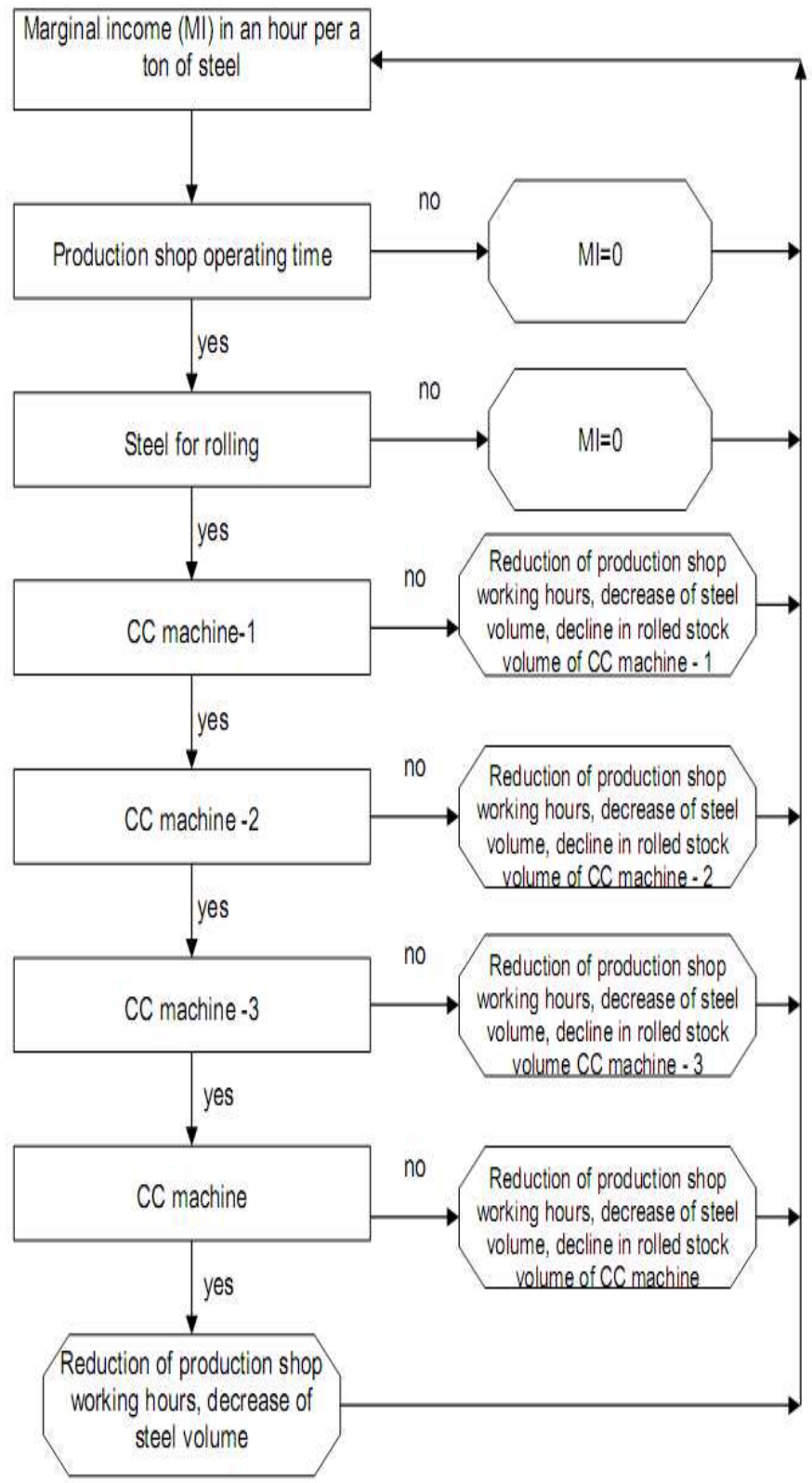

Fig. 3. Structure of the stock of orders optimisation algorithm

After passing through all the stages, the amount of the marginal income of a chosen bar equals zero, so that after the next ranking, this rolled metal does not fall into the check condition and will not be taken into production again.

To write the algorithm standard Microsoft Excel tools were used. The algorithm consists of two sheets: "Restrictions" and "Initial data".

«Initial data» sheet. Name of the product, units of measurement, grade of steel, strength class and cost are filled at Economic Department of the iron and steel company on the basis of the current price list for next month. Filling time before the 15 th day of the month preceding introduction of the price list, if the protocol and the price list for the rolled metal are changed.

Data on variable costs, production shops, types of billets are recorded by Economic Department on the basis of planned variable costs. They are filled monthly up to the 15 th day of the previous month on the basis of planned data for the current month. Steel consumption in the rolling shops, consumption of steel in the crimping shop and productivity are recorded at Production and Management Department on the basis of officially approved rates of metal consumption for rolling, norms of hourly output and labor coefficients.

"Restrictions" sheet is filled at Production-Regulatory Department. It includes records on each shop working time, amount of rolled metal that this shop can roll, volume of the $\mathrm{CC}$-machines rolled products (continuous casting machines), and also the planned yield of steel at the iron and steel company for next month.

Data on the domestic market order volume, order volume for export and the remaining goods are filled into the "Initial Data" sheet at Sales Department and Department on Foreign Economic Activities in accordance with all the incoming to the iron and steel company requests.

After filling all the data in, the "Calculation" button in the programme menu is pushed. Consequently, the "Result" sheet will be automatically created some time after the calculations.

After all the calculations are done, a balance of working hours at the rolling shops of the iron and steel company can be done with the help of the "Balance" button. Thus, data on the possible reduction of losses, which do not add value to customers, will be generated according to the units of the iron and steel company.

Application of practical recommendations of the research will allow shareholders, investors and managers to provide integrated solutions to the problems of iron and steel companies profit increase under risks minimizing and make the solutions scientifically-based while avoiding unnecessary social and economic losses. The proposed approaches and tools are designed to address planning, forecasting and effective development of steel-producing issues in conditions of innovation economics.

\section{RESULTS AND DISCUSSION}

Indexed data obtained from Sales Department and Department on Foreign Economic Activities of JSC "EVRAZ-NTMK" for the $2^{\text {nd }}$ quarter of 2016 were used for 
the analysis. The results of calculations are presented in Table III.

TABLE III. RESULTS OF IMPLEMENTATION OF THE STOCK OF ORDERS OPTIMIZATION ALGORITHM AT JSC "EVRAZ-NTMK” IN TERMS OF MARGINAL PROFIT INCREASE, RUB

\begin{tabular}{|l|c|c|c|}
\hline Month & $\begin{array}{c}\text { Marginal profit } \\
\text { from the rolled } \\
\text { metal taken for } \\
\text { sales }\end{array}$ & $\begin{array}{c}\text { Marginal profit } \\
\text { from the optimum } \\
\text { rolled volume } \\
\text { according to the } \\
\text { calculations }\end{array}$ & Lost profit \\
\hline April & 747107709 & 754792388 & 7684679 \\
\hline May & 734675732 & 756259207 & 21583476 \\
\hline June & 741632840 & 753120117 & 11487278 \\
\hline Total & & & 40755432 \\
\hline
\end{tabular}

Therefore, it can be concluded that:

- lost profit for April amounted to $7.5 \mathrm{mln}$ rubles, for May - $21.5 \mathrm{mln}$ rubles, for June - $11.5 \mathrm{mln}$ rubles.

- total lost profit for the second quarter of 2016 amounted to $40.5 \mathrm{mln}$ rubles.

It should be noted that reduction of losses is achieved by decreasing the costs necessary for calculating. Data on the costs of calculating without model implementation are given in Table IV.

TABLE IV. COSTS FOR CARRYING OUT CALCULATIONS BEFORE THE MODEL IMPLEMENTATION

\begin{tabular}{|l|c|c|c|}
\hline \multicolumn{1}{|c|}{ Stage of calculation } & $\begin{array}{c}\text { Most } \\
\text { probable } \\
\text { time, hour }\end{array}$ & $\begin{array}{c}\text { Average } \\
\text { salary, RUB } \\
\text { / hour }\end{array}$ & $\begin{array}{c}\text { Total } \\
\text { costs, } \\
\text { RUB }\end{array}$ \\
\hline $\begin{array}{l}\text { Analysis of marginal profit } \\
\text { reports for the quarter, } \\
\text { determining of loss-making } \\
\text { bar shapes }\end{array}$ & 8 & 60.2 & 481.6 \\
\hline Calculating & 32 & 60.2 & 1926.4 \\
\hline $\begin{array}{l}\text { Preparation of explanatory } \\
\text { note }\end{array}$ & 5 & 60.2 & 301 \\
\hline Total & 45 & & 2709 \\
\hline
\end{tabular}

Data on calculations costs after model implementation are provided in Table $\mathrm{V}$.

TABLE V. CALCULATIONS COSTS AFTER MODEL IMPLEMENTATION

\begin{tabular}{|l|c|c|c|}
\hline \multicolumn{1}{|c|}{ Stage of calculation } & $\begin{array}{c}\text { Most } \\
\text { probable } \\
\text { time, hour }\end{array}$ & $\begin{array}{c}\text { Average } \\
\text { salary, RUB / } \\
\text { hour }\end{array}$ & $\begin{array}{c}\text { Total } \\
\text { costs, } \\
\text { RUB }\end{array}$ \\
\hline Calculating & 32 & 60.2 & 1926.4 \\
\hline $\begin{array}{l}\text { Preparation of } \\
\text { explanatory note }\end{array}$ & 5 & 60.2 & 301 \\
\hline Total & 43 & & 2274.4 \\
\hline
\end{tabular}

Therefore, if the model is implemented, calculations costs decrease by: $2709-2274.4=481.6 \mathrm{rub} /$ calculation

TABLE VI. RESULTS OF IMPLEMENTATION OF THE ORDERS PORTFOLIO OPTIMIZATION MODEL FOR JSC "EVRAZ-NTMK" IN TERMS OF CALCULATION COSTS REDUCTION

\begin{tabular}{|l|c|c|c|}
\hline Month & $\begin{array}{c}\text { Costs caused by } \\
\text { carrying out } \\
\text { marginal income } \\
\text { analysis before the } \\
\text { model } \\
\text { implementation }\end{array}$ & $\begin{array}{c}\text { Costs caused by } \\
\text { carrying out } \\
\text { marginal income } \\
\text { analysis after the } \\
\text { model } \\
\text { implementation }\end{array}$ & $\begin{array}{c}\text { Lost } \\
\text { profit }\end{array}$ \\
\hline $2^{\text {nd }}$ quarter & $2709 * 2=5418$ & $2274.4 * 2=4454,8$ & 963.2 \\
\hline Total & & & 963.2 \\
\hline
\end{tabular}

Approximately 2 calculations connected with the orders portfolio optimization are performed during a quarter, while the algorithm makes it possible to control the situation of the marginal profit monthly (Table VI).

Therefore, effect of the second quarter of work after the model implementation will account to: $481.6 * 2=963.2$ rub.

TABLE VII. AVERAGE TOTAL LABOUR INTENSITY OF ONE CALCULATION MADE BEFORE THE ALGORITHM IMPLEMENTATION

\begin{tabular}{|l|c|c|c|c|}
\hline \multicolumn{1}{|c|}{$\begin{array}{c}\text { Stage of } \\
\text { calculation }\end{array}$} & $\begin{array}{c}\text { Unit of } \\
\text { measure } \\
\text { ment }\end{array}$ & $\begin{array}{c}\text { Time } \\
\text { (minimum) }\end{array}$ & $\begin{array}{c}\text { Time } \\
\text { (maximum) }\end{array}$ & $\begin{array}{c}\text { Time } \\
\text { (most } \\
\text { probable) }\end{array}$ \\
\hline $\begin{array}{l}\text { Analysis of } \\
\text { marginal profit } \\
\text { reports for the } \\
\text { quarter, } \\
\text { determining of } \\
\text { loss-making bar } \\
\text { shapes }\end{array}$ & Hour & 7.5 & 8.5 & 8 \\
\hline Calculating & Hour & 25 & 39 & 32 \\
\hline $\begin{array}{l}\text { Preparation of } \\
\text { explanatory note }\end{array}$ & Hour & 3 & 6 & 5 \\
\hline Total & Hour & 35.5 & 53.5 & 45 \\
\hline
\end{tabular}

Total labour intensity - time spent for calculating by all the employees involved in the calculation process. It consists of the calculation time itself, time required for preparing of input information, etc. Average total labour intensity without use of the algorithm is shown in Table VII.

Data are calculated on the basis of assumption that duration of one working day is 8 hours.

Average total labour intensity of one calculation made after the algorithm implementation is shown in Table VIII. 
TABLE VIII AVERAGE TOTAL LABOUR INTENSITY OF ONE CALCULATION MADE AFTER THE ALGORITHM IMPLEMENTATION

\begin{tabular}{|l|c|c|c|c|}
\hline $\begin{array}{c}\text { Stage of } \\
\text { calculation }\end{array}$ & $\begin{array}{c}\text { Unit of } \\
\text { measure } \\
\text { ment }\end{array}$ & $\begin{array}{c}\text { Time } \\
\text { (minimum) }\end{array}$ & $\begin{array}{c}\text { Time } \\
\text { (maximum) }\end{array}$ & $\begin{array}{c}\text { Time } \\
\text { (most } \\
\text { probable) }\end{array}$ \\
\hline Calculating & Days & 25 & 39 & 32 \\
\hline $\begin{array}{l}\text { Preparation of } \\
\text { explanatory } \\
\text { note }\end{array}$ & Hour & 3 & 6 & 5 \\
\hline Total & Hour & 28 & 45 & 37 \\
\hline
\end{tabular}

Data are calculated based on assumption that duration of one working day is 8 hours. Effect is calculated based on the fact that two calculations of marginal income are performed during the quarter (Table IX).

TABLE IX. RESULTS OF THE ORDERS PORTFOLIO OPTIMIZATION ALGORITHM FOR JSC "EVRAZ-NTMK" IN TERMS OF TOTAL LABOUR INTENSITY REDUCTION

\begin{tabular}{|l|c|c|c|}
\hline Month & $\begin{array}{c}\text { Costs caused by } \\
\text { carrying out } \\
\text { marginal profit } \\
\text { analysis before } \\
\text { the model } \\
\text { implementation }\end{array}$ & $\begin{array}{c}\text { Costs caused by } \\
\text { carrying out } \\
\text { marginal profit } \\
\text { analysis after the } \\
\text { model } \\
\text { implementation }\end{array}$ & $\begin{array}{c}\text { Lost } \\
\text { profit }\end{array}$ \\
\hline 2 nd quarter & $45^{*} 2=90$ & $37^{*} 2=74$ & 16 \\
\hline Total & & & 16 \\
\hline
\end{tabular}

Therefore, effect of the second quarter of work after the model implementation will be: $45 * 2-37 * 2=16$ hours.

Implementation of the algorithm into JSC "EVRAZNTMK" work has allowed to reduce losses of overproduction of rolled metal, losses for calculations themselves - "losses from expectations", and to increase marginal income of iron and steel companies.

\section{CONCLUSION}

The results of the calculations made in accordance with the author's algorithm demonstrate that the environment uncertainty level at industrial enterprises in Russia is rather high, and consequently, synergetic and complementary approaches to innovation activity management at such enterprises are needed. For decreasing the environment uncertainty level, the orders optimisation algorithm is proposed.

Recently, a trend of changing marginal profit at iron and steel companies could be seen. Gradually, rolling bar stock with negative marginal income becomes profitable.

The survey has shown that the most profitable rolling bar stocks for JSC "EVRAZ NTMK" are I-beams, rails, dowels and round bars. The least profitable are the balls, the axle billet and sheets.
The proposed algorithm for optimizing iron and steel companies' orders portfolio, based on the marginal analysis, has made it possible to economically justify the necessity of lean manufacturing tools implementation for companies operating in the industry under innovation economics and to reduce losses from expectations and overproduction, which do not add value to consumer.

\section{Acknowledgment}

This work was supported by the Russian Science Foundation, project no. 15-18-10014 «Projection of optimal socio-economic systems in turbulence of external and internal environment»

\section{References}

[1] L. Iurieva, M. Kazakova, and E. Dolzhenkova, "Costs management accounting at industrial enterprises in conditions of the innovation economics," - Moscow: RUSCIENCE, 2015, 290 p.

[2] M. Biewen, and C. Weiser, "An empirical test of marginal productivity theory," Applied Economics, vol. 46 (9), pp. 996-1020, March 2014.

[3] A. Snow, and R.S., Jr. Warren, "Pigou's Law and the proportionality of income and price elasticities of demand," Economics Letters, vol. 132, pp. 136-138, July 2015.

[4] D. Murphy, "Excess capacity in a fixed-cost economy," European Economic Review, vol. 91, pp. 245-260, January 2017.

[5] J. Sahno, E. Shevtshenko, T. Karaulova, and K. Tahera, "Framework for continuous improvement of production processes," Inzinerine Ekonomika-Engineering Economics, vol. 26(2), pp. 169-180, 2015.

[6] J. Sahno, and E. Shevtshenko, "Quality Improvement Methodologies for Continuous Improvement of Production Processes and Product Quality and Their Evolution," 9th International DAAAM Baltic Conference Industrial Engineering, pp. 181-186, 2014.

[7] J. Sahno, R. Opik, M. Kostina, M. Paavel, E. Shevtshenko, and Y. Wang, "Knowledge Management Framework for Production Route Selection in Manufacturing Enterprises," 8th International DAAAM Baltic Conference Industrial Engineering, pp. 567-572, 2012.

[8] C. Breuer, G. Siestrup, H.-D. Haasis, and H. Wildebrand, "Collaborative risk management in sensitive logistics nodes," Team Performance Management, vol. 19(7), pp. 331-351, 2013.

[9] F. Wiengarten, B. Fynes, and G. Onofrei, "Exploring synergetic effects between investments in environmental and quality/lean practices in supply chains," Supply Chain Management, vol. 18(2), pp. 148-160, 2013.

[10] A. Paulraj, "Understanding the relationships between internal resources and capabilities, sustainable supply management and organizational sustainability," Journal of Supply Chain Management, 47(1), pp. 19-37, 2011.

[11] A. Paulraj, and I.J. Chen, "Strategic buyer-supplier relationships, information technology and external logistics integration," Journal of Supply Chain Management, vol. 43(2), pp. 2-14, 2007.

[12] M. Holweg, "The genealogy of lean production," Journal of Operations Management, vol. 25(2), pp. 420-437, 2007.

[13] S. Sakakibara, B.B. Flynn, R.G. Schroeder, and W.T. Morris, "The impact of just-in-time manufacturing and its infrastructure on manufacturing performance," Management Science, vol. 43(9), pp. 1246-1257, 1997.

[14] N.M. Alsharari, "Results based costing (RBC) system: Questioning the unit of analysis in ABC," Corporate Ownership and Control, vol. 13(2), pp. 587-603, 2016. 
[15] D. Askarany, H. Yazdifar, and S. Askary, "Supply chain management, activity-based costing and organisational factors," International Journal of Production Economics, vol. 127(2), pp. 238-248, 2010.

[16] K.H. Borch, "The economics of uncertainty," Princeton: Princeton University Press, p. 227, 2015.
[17] M. Marinacci, "Model uncertainty," Journal of the European Economic Association, vol. 13(6), pp. 1022-1100, 2015.

[18] Ya. Li, Yo. Li, and Y. Zhao, "Fang Wang Which Factor Dominates the Industry Evolution? A Synergy Analysis Based on China's ICT Industry," Inzinerine Ekonomika-Engineering Economics, vol. 25(3), pp. 273-282, 2014 